\title{
HEALTH STATUS OF GENE FOND DONOR COWS OF LATVIAN NATIVE BREEDS LATVIAN BROWN AND LATVIAN BLUE
}

\author{
Guna Ringa-Karahona, Ilga Sematovica, Vita Antane, Māra Mangale \\ Latvia University of Life Sciences and Technologies, Latvia \\ guna.ringavet@gmail.com
}

\begin{abstract}
The preservation of local animal breeds is a topical theme in recent years. Latvian Brown (LB) and Latvian Blue (LZ) cow breeds are exhausting and must be preserved. It can be performed by the use of multiple ovulation and embryo transfer (MOET). The difficulties exist in choosing the gene-fond (GF) cows as donors caused by the small number of animals. Twenty-three cows were intended for donor cow's role from different herds until September 2018, and twenty of them were accepted. Anamnesis, clinical examination, blood morphology (13 parameters) and biochemical indices (19 parameters) were analyzed before MO induction. Three cows were rejected because of ovarian cysts or pyometra, negative energy balance (NEB) (glucose $<2.3 \mathrm{mmol} \mathrm{L}^{-1}$ simultaneously with elevated B-hydroxybutyric acid $>1.4$ mmol L-1) and elevated $(\mathrm{p}<0.05)$ number of leukocytes $\left(28.20 \times 10^{9} \mathrm{~L}^{-1}\right)$. More than $52.6 \%$ of cows had a repeated artificial insemination before the last parturition, and 5.3\% of cows had lifeless offspring in the last parturition. The $1^{\text {st }}$ and $2^{\text {nd }}$ lactation cows were healthier than older cows $(\mathrm{p}<0.05)$. The amount of albumins, cholesterol, triglycerides and $\mathrm{Na}, \mathrm{K}, \mathrm{P}, \mathrm{Cl}, \mathrm{Mg}$ was significantly different in donors with and without successfully obtained embryos $(\mathrm{p}<0.05)$. In conclusion, not only acceptable clinical health but also the cow metabolic status is a decisive factor for success of MOET.
\end{abstract}

Key words: native breed, gene fond cow, health status.

\section{Introduction}

Cow fertility is influenced by a combination of factors. The main ones are related to animal genetics, management and climatic conditions. Complex interactions of these factors make it difficult to determine the exact reason for decline of fertility. Nonetheless, the main causes that have a negative impact on dairy cows' fertility and offspring are identified by scientists. The assessment of the impact of one factor of reproductive performance may be highly confounded. Reproduction can be affected by individual and herd level factors with effects on reproduction including the cow age, season, diseases, nutrition, body condition, environment, herd management decisions, the intensity and accuracy of heat detection, and the use of management programs. Such reasons as poor nutrition, management and environmental factors are often not evaluated in studies for the decline in fertility although they have a significant impact on the reproductive performance. Are metabolic demands for production and reproduction reaching a biological or management limit? Are genetic selection criteria for fertility optimized? These are important and warrant valid questions (LeBlanc, 2010).

Nutrition plays a critical role in the regulation of cow fertility. Cows that have metabolic disorders and/ or gynecological problems are more likely to have lower conception rates and to be culled due to fertility problems (Roche, 2006). Body condition score (BCS) is used to monitor nutritional and health status of cows during their productive cycle. Body condition score at different stages of lactation correlated with improved fertility: genetic correlations between BCS and pregnancy in 63 days after the start of breeding season ranged from 0.29 to 0.42 . (Berry et al., 2003). Cows in low BCS at calving or that suffer excess BCS loss early postpartum are less likely to ovulate. They have a reduced submission rate to artificial insemination and conception rate to the first service. They also have an increased likelihood for pregnancy loss and increased calving to conception interval (Roche, 2006; Roche et al., 2009; Ribeiro et al., 2016). This can partly be attributed to impaired oocyte competence associated with a low BCS (1.5-2.5; 5-point scale) (Snijders et $a l ., 2000)$. Fertility in cows that are over conditioned at calving ( $\mathrm{BCS} \geq 3 ; 5$-point scale) tend to have greater fat mobilization, and therefore a more severe negative energy balance (NEB) in early postpartum period than in cows with an optimum BCS at calving (Roche et al., 2009). Changes in BCS during the transition period affected non-esterified fatty acids (NEFA) and $\beta$-hydroxybutyric (BHB) concentration as well as fertility and occurrence of health problems during the lactation (Roche et al., 2018; Barletta et al., 2017). A successful reproduction depends on the ovulation of an oocyte capable of undergoing fertilization and subsequent embryo and fetal development. As demonstrated in inhibitor studies, subsequent embryo development is significantly influenced by lipolysis and b-oxidation within the maturing cumulusoocitoocytelexes (COCs) (Dunning, Russell, \& Robker, 2014). Metabolic changes in blood serum may be reflected in the biochemical composition of follicular fluid and could indirectly influence oocyte quality. The study to examine the biochemical composition of follicular fluid harvested from different-sized follicles and its relationship with that of blood serum in dairy cattle founded the significant correlation between the composition of serum and follicular fluid for ions 
(sodium, potassium and chloride) and metabolites (glucose, $\beta$-hydroxybutyrate ( $\beta$-OHB), lactate, urea, total protein, triglycerides, non-esterified fatty acids and total cholesterol). Leroy, 2004, detected that follicular fluid concentrations of glucose, $\beta$-OHB and total cholesterol increased from small to large follicles and decreased for potassium, chloride, lactate, urea and triglycerides. The present study suggests that the oocyte and the granulosa cells of dairy cows grow and mature in a biochemical environment that changes from small to large follicles. The significant correlation between the composition of serum and follicular fluid for the above-mentioned metabolites suggests that metabolic changes in serum level will be reflected in the follicular fluid and, therefore, may affect the quality of both the oocyte and the granulosa cells (Leroy et al., 2004). The biochemical serum changes observed in dairy cattle during NEB early postpartum period are well reflected in the follicular fluid of the dominant follicle, this exposing the granulosa cells and maturing oocyte (Leroy et al., 2008). Shabankareh, Kor, Hajarian, 2013, examined the influence of the corpus luteum on metabolite composition of follicular fluid (FF), harvested from different-sized follicles and the relationship between metabolite composition of FF to blood serum in dairy cows. The results showed that serum concentration of glucose, cholesterol and triglyceride was significantly different $(\mathrm{p} \leq 0.05)$ in $\mathrm{FF}$ from follicles of different size categories.

Walsh, Williams, \& Evans, 2011, consider the following points to have the greatest negative impact on fertility and that they need to be prioritized in efforts to ameliorate the problem. Firstly, NEB should be minimized and any infection on the postpartum uterus should be resolved. Secondly, expression and detection of estrus should be performed and followed by insemination with high quality semen (day 0). Thirdly, ovulation and fertilization of a high quality oocyte (day 1) should happen. Fourthly, an early increase in progesterone secretion from the corpus luteum (days 3-7) should follow. Fifthly, the uterine endometrium must produce an early and appropriate environment to stimulate embryo development (days 6-13). This leads to sixthly that is adequate quantities of interferontau (days 14-18) produced by a large embryos that provides signals for maternal recognition of pregnancy (days 16-18) due to decrease of uterine prostaglandin secretion (Walsh, Williams, \& Evans, 2011).

Studies focused on investigation the effects of uterus inflammatory diseases before cow breeding on fertilization and embryo development were provided. Reduced cleavage of potential zygotes, reduced survival of zygotes to the morula stage, impaired development to early stages of conceptus elongation, an increased pregnancy loss, and consequently, reduced pregnancy and calving per breeding (Ribeiro et al., 2016) were reported.

In order to preserve Latvian Brown (LB) and Latvian Blue (LZ) native cow breeds by using multiple ovulation and embryo transfer (MOET), the project BioReproLV was started by the Faculty of Veterinary Medicine, Latvia University of Life Sciences and Technologies. The Latvian Brown (LB) and Latvian Blue (LZ) dairy cows are the native cattle breeds and characteristic to Latvia exclusively. During last years, the number of these animals has decreased continuously. Since LB and LZ breeds are national wealth, responsibility of the government and related institutions is to take care of preservation, rational use and further development of these breeds. That is why the best animals of the population have been selected, based on their origin and productivity, and approved as gene fond (GF) animals. By data available of Animal Breeders Association of Latvia, in 2013, only 123 LB cows were confirmed as GF animals, and about $300 \mathrm{LZ}$ cows in 2015-2018.

Selection of gene-fond (GF) animals, included in the project BioReproLV , is performed by pedigree experts and partners of the project Animal Breeders Association of Latvia. Although GF animals are of superior genetical value, it is also necessary to be in adequate health status to get good response to $\mathrm{MO}$ and embryos of adequate quality.

The problem is that many of the GF animals are housed on small farms without calculated feeding ration. Many of farmers owning GF animals do not have appropriate level of knowledge relevant to the cow physiology, feeding, sanitary conditions, and breeding. It was clear that in natural conditions these GF animals and native breeds in Latvia would die out despite of having some governmental programs and support.

The aim of this study is to detect the health status in 23 GF donor cows intended for MOET.

\section{Materials and Methods}

Twenty-three GF cows were intended as donor cows from different herds during 2017 and 2018, and 20 of them were included to be donor cows. Because of small number of animals no further differentiation between breeds was performed in interpretation of results. Short anamnesis of recent health disorders and clinical symptoms, age, number of lactations were collected from owners. An investigation of health status was performed before induction of MO. The general clinical examination (pulse, respiratory rate, rectal temperature, rumination, consistence of feces), and evaluation of reproductive tract as well as the body condition score (BCS) were performed. Blood samples were collected to establish such parameters as blood morphology (red blood cells 
(RBC)), hemoglobin (Hgb), hematocrit (PCV), mean corpuscular volume (MCV), mean corpuscular $\mathrm{Hgb}(\mathrm{MCH})$, mean corpuscular Hgb concentration (MCHC), white blood cells (WBC), platelets (PLT), band neutrophils (St), segmented neutrophils $(\mathrm{Sg})$, eosinophils (Eo), lymphocytes (Ly), monocytes (Mo)) and biochemical analysis (alanine aminotransferase (ALT), aspartate aminotransferase (AST), gamma glutamyl-transferase (GGT), alkaline phosphatase (ALP), lactate dehydrogenase (LDH), urea, creatinine (CREA), total protein (TP), albumin, sodium (Na), potassium $(\mathrm{K})$, calcium $(\mathrm{Ca})$, phosphorus $(\mathrm{P})$, chloride $(\mathrm{Cl})$, magnesium $(\mathrm{Mg})$, cholesterol (CHOL), triglycerides (TRG)). Blood morphological and biochemical analyses were performed in accredited laboratories - 'Centrālā Laboratorija' (LVS EN ISO 15189:2013; LATAK-M-434-04-2011) and Food safety, Animal Health and Environment Institute 'BIOR' (LVS EN ISO/IEC 17025:2005; LVS EN ISO 15189:2013). Express tests were performed on the farm to detect the concentration of glucose (Glc) and B-hydroxybutyric acid (BHB) in the cows' blood using FreeStyle Optium Neo. Reference values were adapted from Latimer, Duncan \& Prasses, 2011 and Kaneko, Harvey, \& Bruss, 2018. Blood samples were taken from the caudal vein applying venipuncture. The area of puncture was cleaned with $70 \%$ ethanol before sampling. Blood samples were collected in 5 $\mathrm{mL}$ vacutainers containing clot activator, and in $3 \mathrm{~mL}$ vacutainers containing ethylenediaminetetraacetic acid (EDTA) (for blood morphology and biochemistry, respectively). Blood samples were cooled immediately and stored in $+4{ }^{\circ} \mathrm{C}$ till delivery to laboratory. Express tests were performed using fresh blood immediately after obtaining.

Statistical parameters of data such as mean values and the standard deviation, two independent samples t-test were calculated using $R$ Commander Version 2.4-1 (RStudio).

\section{Results and Discussion}

There are many important factors to be considered for successful MOET in a cow (Mikkola, 2017; Marie, 1999). A good herd and individual cow reproductive health (Kohrama \& Poorhamdollaha, 2012), appropriate metabolic status (Gabriel \& Reuben, 2014), age, successful parturition, optimal indices of artificial insemination (AI) in a herd and individual cow, welfare and housing conditions (Abdelattya et al., 2018), kind of protocol (Barusellia et al., 2011) and medicines to induce MO (Mikkola \& Taponen, 2017), embryo flushing method, staff qualification and experience - these and many other common and individual factors are important for successful MOET.

No recent health disorders or clinical symptoms in GF donor cows were observed by the owners. Many of GF animals are in age, they live on small farms without calculated feeding ration, but nutrition plays a critical role in the regulation of cow fertility (LeBlanc, 2010). Many of these small private farm owners do not have appropriate education regarding the cow physiology, feeding and sanitary. These conditions could be the reason for reproductive inaccuracies and MOET failure.

More than $52.6 \%$ of cows had repeated artificial insemination before the last parturition, and 5.3\% of cows had lifeless offspring in the last parturition. The reasons had not been established neither by the owners nor local vets.

The average age of donors was $6.6 \pm 3.61$ years. The oldest cow was 15 years old and had 13 lactations. Superovulation success depends on the cow's age because the amount of gonadotropin responsive follicles decreases with the age (Malhi et al., 2008). Only 4 or $21.1 \%$ were primiparous cows, 10 cows or $52.6 \%$ were older than the third lactation, but $15.9 \%$ of cows had more than 7 lactations.

No inaccuracies regarding the general health parameters were detected in all intended cows. Due to the results of reproductive tract examination, $20 \mathrm{GF}$ cows were accepted as donors. Initially, there were $23 \mathrm{GF}$ cows intended for MOET, but 3 cows were rejected because of ovarian cysts or pyometra, negative energy balance (Glc above $2.3 \mathrm{mmol} \mathrm{L}^{-1}$ simultaneously with elevated BHB above $\left.1.4 \mathrm{mmol} \mathrm{L}^{-1}\right)$.

The average $\mathrm{BCS}$ was $3.0 \pm 0.50$ points, the range was from 1 to 4.5 points, where 1 point denotes very thin, and 5 points denote an excessively fat cow. Cows in low BCS at calving, or that suffer excess BCS have impaired fertility (Berry, Roshe, \& Coffey, 2007; Roche, 2006; Roche et al., 2009; Snijders et al., 2000). Changes in BCS during three weeks prepartum until three weeks postpartum affected NEFA and BHB concentrations, fertility, and occurrence of health problems during the lactation (Barletta et al., 2017).

Blood morphological parameters (Table 1) were basically in reference ranges except one cow had a slightly elevated WBC $\left(13.10 \times 10^{9} \mathrm{~L}^{-1}\right)$, and one had a significantly $(\mathrm{p}<0.05)$ elevated WBC $\left(28.20 \times 10^{9} \mathrm{~L}^{-1}\right)$, but it was not related to the reproductive system disorders clinically; anyway, this cow was rejected. Also, MCV and MCHC were elevated in two oldest cows, and it was not related to any clinical signs of illness. Elevated St and Sg were in cows which were rejected to be the donor cows.

Primiparous cows had more $\mathrm{RBC}$ and $\mathrm{MCHC}$ in comparison with multiparous cows $(p<0.05)$ and elevated $\mathrm{Sg}$ which could be evidence of subacute or chronic inflammation process. Despite of the fact that parameters were in reference ranges, multiparous cow had more Htc, St and Ly $(\mathrm{p}<0.05)$, and it proves that older cow group cows had cows chronic inflammation 
Table 1

Blood morphological parameters in intended cow for MOET (compared in three categories: primiparous versus multiparous cows, cows which had embryos versus the ones who did not have and cows accepted for a donor role versus those denied)

\begin{tabular}{|c|c|c|c|c|c|c|}
\hline Parameters & $\begin{array}{l}\text { Primiparous } \\
\text { cows } \\
(n=3)\end{array}$ & $\begin{array}{c}\text { Multiparous } \\
\text { cows } \\
(n=17)\end{array}$ & $\begin{array}{l}\text { Cows which } \\
\text { had embryos } \\
\quad(n=9)\end{array}$ & $\begin{array}{c}\text { Cows which } \\
\text { did not have } \\
\text { embryos } \\
(\mathrm{n}=11)\end{array}$ & $\begin{array}{c}\text { Accepted for a } \\
\text { donor role } \\
(n=20)\end{array}$ & $\begin{array}{c}\text { Denied for a } \\
\text { donor role } \\
\quad(n=3)\end{array}$ \\
\hline $\operatorname{RBC}\left(10^{12} \mathrm{~g} \mathrm{~L}^{-1}\right)$ & $6.3 \pm 0.12 *$ & $5.9 \pm 0.62$ & $6.00 \pm 0.66$ & $6.0 \pm 0.55$ & $6.0 \pm 0.60$ & $6.1 \pm 0.44$ \\
\hline $\operatorname{Hbg}\left(\mathrm{g} \mathrm{dL}^{-1}\right)$ & $10.0 \pm 0.15$ & $10.0 \pm 1.05$ & $9.73 \pm 1.00$ & $10.1 \pm 0.92$ & $10.0 \pm 1.01$ & $10.2 \pm 0.32$ \\
\hline Htc $(\%)$ & $26.4 \pm 2.47$ & $29.8 \pm 3.32 *$ & $29.70 \pm 4.24$ & $29.0 \pm 2.95$ & $29.2 \pm 3.63$ & $29.5 \pm 0.32$ \\
\hline MCV (fL) & $41.6 \pm 3.22$ & $50.4 \pm 4.34 *$ & $49.72 \pm 5.77$ & $48.5 \pm 5.04$ & $48.9 \pm 5.52$ & $49.0 \pm 3.16$ \\
\hline $\mathrm{MCH}(\mathrm{pg})$ & $15.8 \pm 0.34$ & $16.9 \pm 1.72$ & $16.24 \pm 1.54$ & $16.9 \pm 1.63$ & $16.7 \pm 1.63$ & $16.9 \pm 16.87$ \\
\hline $\mathrm{MCHC}\left(\mathrm{g} \mathrm{dL}^{-1}\right)$ & $38.2 \pm 3.66^{*}$ & $32.6 \pm 4.85$ & $30.35 \pm 6.45$ & $35.1 \pm 3.34^{*}$ & $33.4 \pm 5.38$ & $34.6 \pm 1.42$ \\
\hline WBC $\left(10^{9} \mathrm{~L}^{-1}\right)$ & $7.6 \pm 0.11$ & $8.3 \pm 2.16$ & $9.35 \pm 2.30$ & $9.3 \pm 5.95$ & $8.1 \pm 2.10$ & $18.6 \pm 10.17 *$ \\
\hline $\operatorname{PLT}\left(10^{9} \mathrm{~L}^{-1}\right)$ & $401 \pm 239.7$ & $378 \pm 140.8$ & $464 \pm 157.9^{*}$ & $349 \pm 150.9$ & $363 \pm 148.9$ & $531 \pm 179.2^{*}$ \\
\hline St $(\%)$ & $0.3 \pm 0.49$ & $2.4 \pm 1.73^{*}$ & $2.20 \pm 1.63$ & $1.9 \pm 1.82$ & $2.0 \pm 1.84$ & $2.0 \pm 1.05$ \\
\hline $\operatorname{Sg}(\%)$ & $51.3 \pm 6.34 *$ & $35.5 \pm 8.24$ & $32.50 \pm 11.32$ & $40.9 \pm 7.82 *$ & $37.6 \pm 10.26$ & $42.5 \pm 4.74 *$ \\
\hline Eo $(\%)$ & $8.3 \pm 4.17$ & $8.0 \pm 8.06$ & $12.5 \pm 10.57 *$ & $5.6 \pm 3.26$ & $8.5 \pm 7.90^{*}$ & $5.0 \pm 0.01$ \\
\hline Ly $(\%)$ & $34.0 \pm 3.05$ & $48.3 \pm 7.79^{*}$ & $44.83 \pm 10.53$ & $46.5 \pm 8.15$ & $46.5 \pm 9.30$ & $41.5 \pm 3.69$ \\
\hline Mo (\%) & $5.1 \pm 3.77$ & $6.3 \pm 2.93$ & $7.67 \pm 3.60 *$ & $5.2 \pm 2.42$ & $5.7 \pm 3.17$ & $8.5 \pm 0.53 *$ \\
\hline
\end{tabular}

$* \mathrm{p}<0.05$

process and it could impair embryo harvest. In cows which had no embryos this parameter was closely to upper physiological value or elevated. Cows denied for donor role had elevated WBC $(\mathrm{p}<0.05)$.

A traditional way to establish cow's internal health and metabolic status is evaluating of blood biochemical parameters (Table 2). It was proved by former investigations that embryo size and quality depend on the level of Glc in blood (Son et al., 2012). In our study, primiparous cows had a higher level of Glc $\left(3.3 \pm 0.71 \mathrm{mmol} \mathrm{L}^{-1}\right)$ in comparison with multiparous $\left(2.7 \pm 0.58 \mathrm{mmol} \mathrm{L}^{-1}\right)$ cows $(\mathrm{p}<0.05)$. In cows which were accepted for a donor role, the level of Glc was significantly higher than in the rejected cows $(3.0 \pm$ 0.68 and $2.5 \pm 0.05 \mathrm{mmol} \mathrm{L}^{-1}$, respectively). Regarding the harvest of embryos from all cows together, the difference of Glc did not differ significantly (2.8 \pm $0.43 ; 2.9 \pm 0.76 \mathrm{mmol} \mathrm{L}^{-1}$, respectively, $\left.\mathrm{p}>0.05\right)$, but the level of BHB was significantly higher in cows with poor harvest of embryos $(1.2 \pm 0.45 ; 0.67 \pm 0.21$ mmol L-1, respectively, $\mathrm{p}<0.001)$.

Fertility in cows that are over conditioned at calving ( $\mathrm{BCS} \geq 3$; 5-point scale) tend to have greater fat mobilization, and therefore a more severe NEB in postpartum period than cows with an optimum BCS at calving (Roche et al., 2009).

A multiparous cow had an impaired liver health (GGT, ALAT, ASAT, LDH together), and those parameters differed from primiparous cow results significantly $(\mathrm{p}<0.05)$.
T-test for independent samples of blood biochemical parameters in cows with good expression of $\mathrm{MO}$ and cows with a poor reaction to medicines inducing $\mathrm{MO}$ was conducted. In cows with a good $\mathrm{MO}$ expression there was more RBC $(6.2 \pm 0.61$ and $5.7 \pm 0.42 \times 10^{12} \mathrm{~g} \mathrm{~L}^{-1}$, respectively), Alb (32.7 \pm 4.95 and $29.8 \pm 2.07 \mathrm{~g} \mathrm{~L}^{-1}$, respectively). They were better provided with $\mathrm{Cl}, \mathrm{Mg}$ and had optimal $\mathrm{CHOL}(4.5 \pm 1.4$ vs $3.9 \pm 0.85\left(\mathrm{mmol} \mathrm{L}^{-1}\right)$. Significant correlations were also observed by Leroy, 2004, for total cholesterol and large follicles in cow ovaries $(\mathrm{r}=0.42 ; \mathrm{p}<0.05)$.

\section{Conclusions}

1. Despite the genetic value and such parameters as acceptable anamnesis, age, the number of lactations and results of general clinical examination of GF cows are not enough to accept GF animal as a donor.

2. Results of reproductive tract examination and BCS are the very first signals to accept or reject GF animal as a donor. Non acceptable results of reproductive tract examination and BCS can also be useful signals not to perform on-farm express tests and any further laboratory tests.

3. On-farm express tests are useful tools to make decision for further laboratory tests or specific treatment of animal before accepting it as a donor.

4. Results of hematology and biochemistry are the very last parameters to accept or reject GF animal as a donor. These results allow to foresee the 
Table 2

Results of blood biochemical parameters in cows intended for MOET (compared in three categories: primiparous versus multiparous cows, cows which had embryos versus cows which did not have and cows accepted for a donor role versus those denied)

\begin{tabular}{|c|c|c|c|c|c|c|}
\hline Parameters & $\begin{array}{c}\text { Primiparous } \\
\text { cows } \\
(\mathrm{n}=3)\end{array}$ & $\begin{array}{l}\text { Multiparous } \\
\text { cows } \\
(n=17)\end{array}$ & $\begin{array}{l}\text { Cows which } \\
\text { had embryos } \\
\quad(n=9)\end{array}$ & $\begin{array}{l}\text { Cows which did } \\
\text { not have embryos } \\
(\mathrm{n}=11)\end{array}$ & $\begin{array}{l}\text { Accepted for } \\
\text { a donor role } \\
(n=20)\end{array}$ & $\begin{array}{c}\text { Denied for a } \\
\text { donor role } \\
(n=3)\end{array}$ \\
\hline $\operatorname{ALAT}\left(\mathrm{U} \mathrm{L}^{-1}\right)$ & $31.1 \pm 2.36$ & $33.9 \pm 10.77^{*}$ & $31.0 \pm 14.20$ & $34.6 \pm 6.69$ & $32.8 \pm 10.23$ & $38.0 \pm 5.27$ \\
\hline $\operatorname{ASAT}\left(\mathrm{U} \mathrm{L}^{-1}\right)$ & $99.8 \pm 21.16^{*}$ & $79.5 \pm 16.53$ & $78.3 \pm 21.23$ & $85.2 \pm 17.27$ & $8.3 \pm 19.92$ & $79.5 \pm 3.69$ \\
\hline $\operatorname{GGT}\left(\mathrm{U} \mathrm{L}^{-1}\right)$ & $21.1 \pm 5.30$ & $33.1 \pm 8.15^{*}$ & $30.5 \pm 7.78$ & $31.3 \pm 9.62$ & $3.5 \pm 8.69$ & $35.0 \pm 10.54$ \\
\hline $\operatorname{ALP}\left(\mathrm{U} \mathrm{L}^{-1}\right)$ & $\begin{array}{l}145.5 \pm \\
133.97 *\end{array}$ & $45.1 \pm 14.72$ & $52.5 \pm 18.24$ & $66.5 \pm 80.23$ & $64.7 \pm 69.97 *$ & $38.5 \pm 6.85$ \\
\hline $\mathrm{LDH}\left(\mathrm{U} \mathrm{L}^{-1}\right)$ & $1941 \pm 659.7 *$ & $1063 \pm 208.0^{*}$ & $1003 \pm 270.3$ & $1335 \pm 515.7$ & $1244 \pm 495.7$ & $1022 \pm 19.5$ \\
\hline $\operatorname{UREA}\left(\mathrm{mmol} \mathrm{L}^{-1}\right)$ & $5.1 \pm 1.62^{*}$ & $3.5 \pm 1.60$ & $3.9 \pm 1.85$ & $3.7 \pm 1.63$ & $3.5 \pm 1.56$ & $5.6 \pm 1.74^{*}$ \\
\hline $\operatorname{CREA}\left(\mathrm{mmol} \mathrm{L}^{-1}\right)$ & $35.9 \pm 35.37$ & $78.5 \pm 16.25^{*}$ & $71.9 \pm 11.57$ & $74.4 \pm 28.15$ & $74.4 \pm 25.00$ & $67.1 \pm 2.58$ \\
\hline $\mathrm{TP}\left(\mathrm{g} \mathrm{L}^{-1}\right)$ & $73.2 \pm 1.52$ & $74.7 \pm 5.66$ & $75.5 \pm 7.67$ & $73.9 \pm 3.36$ & $74.4 \pm 5.54$ & $75.0 \pm 0.00$ \\
\hline Alb $\left(\mathrm{g} \mathrm{L}^{-1}\right)$ & $37.8 \pm 4.99^{*}$ & $30.7 \pm 3.13$ & $29.2 \pm 3.29$ & $33.3 \pm 4.20^{*}$ & $31.8 \pm 4.59$ & $32.5 \pm 1.58$ \\
\hline $\mathrm{Na}\left(\mathrm{mmol} \mathrm{L}{ }^{-1}\right)$ & $145.0 \pm 0.85^{*}$ & $140.5 \pm 2.08$ & $140.0 \pm 2.35$ & $141.8 \pm 2.46$ & $140.9 \pm 2.51$ & $144.0 \pm 0.00$ \\
\hline $\mathrm{K}(\mathrm{mmol} \mathrm{L}-1)$ & $5.0 \pm 0.58$ & $5.3 \pm 0.40$ & $5.4 \pm 0.55^{*}$ & $5.2 \pm 0.36$ & $5.2 \pm 0.44$ & $5.6 \pm 0.21 *$ \\
\hline $\mathrm{Ca}(\mathrm{mmol} \mathrm{L}-1)$ & $2.3 \pm 0.16$ & $2.4 \pm 0.15$ & $2.4 \pm 0.21$ & $2.4 \pm 0.12$ & $2.4 \pm 0.16$ & $2.5 \pm 0.06$ \\
\hline $\mathrm{P}\left(\mathrm{mmol} \mathrm{L}^{-1}\right)$ & $1.7 \pm 0.26$ & $2.1 \pm 0.28^{*}$ & $2.2 \pm 0.32 *$ & $2.0 \pm 0.28$ & $2.0 \pm 0.33$ & $2.1 \pm 0.02$ \\
\hline $\mathrm{Cl}\left(\mathrm{mmol} \mathrm{L}^{-1}\right)$ & $98.3 \pm 0.98$ & $98.7 \pm 2.00$ & $99.2 \pm 1.37$ & $98.3 \pm 2.03$ & $98.5 \pm 1.95$ & $99.5 \pm 0.53$ \\
\hline $\mathrm{Mg}\left(\mathrm{mmol} \mathrm{L}^{-1}\right)$ & $1.3 \pm 0.27^{*}$ & $1.0 \pm 0.09$ & $1.0 \pm 0.09$ & $1.0 \pm 0.18$ & $1.0 \pm 0.17$ & $1.0 \pm 0.01$ \\
\hline $\mathrm{CHOL}\left(\mathrm{mmol} \mathrm{L}^{-1}\right)$ & $3.9 \pm 0.00$ & $4.4 \pm 1.43$ & $4.0 \pm 1.43$ & $4.7 \pm 1.31^{*}$ & $4.4 \pm 1.48$ & $4.4 \pm 0.54$ \\
\hline TRG $\left(\mathrm{mmol} \mathrm{L}^{-1}\right)$ & $0.1 \pm 0.00$ & $0.2 \pm 0.05^{*}$ & $0.2 \pm 0.07$ & $0.2 \pm 0.04$ & $0.2 \pm 0.05^{*}$ & $0.1 \pm 0.04$ \\
\hline Glc $\left(\mathrm{mmol} \mathrm{L}^{-1}\right)$ & $3.3 \pm 0.71^{*}$ & $2.7 \pm 0.58$ & $2.8 \pm 0.43$ & $2.9 .0 \pm 0.76$ & $3.0 \pm 0.68^{*}$ & $2.5 \pm 0.05$ \\
\hline $\mathrm{BHB}\left(\mathrm{mmol} \mathrm{L}{ }^{-1}\right)$ & $1.0 \pm 0.55$ & $0.9 \pm 0.40$ & $0.7 \pm 0.21$ & $1.2 \pm 0.45^{*}$ & $0.8 \pm 0.35$ & $1.7 \pm 0.26^{*}$ \\
\hline
\end{tabular}

$* \mathrm{p}<0.05$

animal response to $\mathrm{MO}$ and the possible outcome of embryos.

5. Not only good health, but also cow metabolic status is a decisive factor for MOET.

\section{Acknowledgements}

Research is financially supported by ERAF. Project No. 1.1.1.1/16/A/025, BioReproLV.

\section{References}

1. Abdelattya, A.M., Iwaniukb, M.E., Pottsb, S.B., \& Gadc, A. (2018). Influence of maternal nutrition and heat stress on bovine oocyte and embryo development. International Journal of Veterinary Science and Medicine, 6, 1-5.

2. Barletta, R.V., Maturana Filho, M., Carvalho, P.D., Del Valle, T.A., Netto, A.S., Renno, F.P., Mingoti, R.D., Gandra, J.R., Mourão, G.B., Fricke, P.M., Sartori RMadureira, E.H., \& Wiltbank, M.C. (2017). Association of changes among body condition score during the transition period with NEFA and BHBA concentrations, milk production, fertility, and health of Holstein cows. Theriogenelogy, 104, 30-36.

3. Barusellia, P.S., Ferreiraa, R.M., Salesa, J.N.S., Gimenesa, L.U., Sá Filhoa, M.F., Martinsa, C.M., Rodriguesb, C.A., \& Bóc, G.A. (2011). Timed embryo transfer programs for management of donor and recipient cattle. Advances in Bovine Reproduction and Embryo Technology. Theriogenology, 76, 1583-1593.

4. Berry, D.P., Buckley, D. P., Evans, R.D., Rath, M., \& Veerkamp, R.F. (2003). Genetic Relationships among Body Condition Score, Body Weight, Milk Yield and Fertility in Dairy Cows. Journal of Dairy Science, 82, 2193-2204.

5. Berry, D.P., Roche, J.R., \& Coffey, M.P. (2007). Body Condition Score and Fertility - More Than Just a Feeling. Fertility in Dairy Cows - Bridging the gaps Liverpool Hope University, Liverpool, UK, pp. $107-118$. 
6. Dunning, K.R., Russell, D.L., \& Robker, R.L. (2014). Lipids and oocyte developmental compotence: the role of fatty acids and b-oxidation. Reproduction, 148, 15-27. DOI: 10.1530/REP-13-0251.

7. Gabriel, A.B., \& Reuben, J.M. (2014). Historical perspectives and recent research on superovulation in cattle. $40^{\text {th }}$ Anniversary Special Issue. Theriogenology, 81, 38-48.

8. Kaneko, J.J., Harvey, J.W., \& Bruss, M.L. (2018). Clinical Biochemistry of Domestic Animals, $6^{\text {th }}$ Ed., Academic Press, 928 p.

9. Kohrama, H., \& Poorhamdollaha, M. (2012). Relationships between the ovarian status and superovulatory responses in dairy cattle. Animal Reproduction Science, 131, 123-128.

10. Latimer, K.S., Duncan \& Prasse's. (2011). Veterinary Laboratory Medicine: Clinical Pathology, ${ }^{\text {th }}$ Ed., Wiley-Blackwell, $524 \mathrm{p}$.

11. LeBlanc, S. (2010). Assessing the association of the level of milk production with reproductive performance in dairy cattle. Journal of Reproduction and Development, 56, S1-S7.

12. Leroy, J.L.M.R., Vanholder, T., Delanghe, J.R., Opsomer, G., Van Sooma, A., Bols, P.E.J., \& de Kruif, A. (2004). Metabolite and ionic composition of follicular fluid from different-sized follicles and their relationship to serum concentrations in dairy cows. Animal Reproduction Science, 80, 201-211. DOI: 10.1016/S0378-4320(03)00173-8.

13. Leroy, J.L.M.R., VanSoon, A., Opsomer, G., \& Bols, P.E.J. (2008). The consequences of metabolic changes in high - yielding dairy cows on oocyte and embryo quality. Animal, 2(8), 1120-1127. DOI: 10.1017/ S1751731108002383.

14. Malhi, P.S., Adams, G.P., Mapletoft, R.J., \& Singh, J. (2008). Superovulatory response in a bovine model of reproductive aging. Animal Reproduction Science, 109, 100-109.

15. Marie, M. (1999). Links between nutrition and reproduction in cattle. Applied life sciences, Joint FAO/ IAEA Division of Nuclear Techniques in Food and Agriculture, Vienna (Austria), p. 171. ISSN 10114289. Retrieved February 28, 2018, from http:/www.iaea.org/inis/collection/NCLCollectionStore/ Public/30/042/30042858.pdf.

16. Mikkola, M., \& Taponen, J. (2017). Embryo yield in dairy cattle after superovulation with Folltropin or Pluset. Theriogenology, 88, 84-88.

17. Mikkola, M. (2017). Superovulation and embryo transfer in dairy cattle - effect of management factors with emphasis on sex-sorted semen. Academic dissertation, p. 79. Retrieved March 3, 2018, from https:// helda.helsinki.fi/bitstream/handle/10138/183817/Superovu.pdf?sequence=1.

18. Ribeiro, E.S., Gomes, G., Greco, L.F., Cerri, R.L.A., Vieira-Neto, A., Monteiro, P.L.J., Lima, F.S., Bisinotto, R.S., Thatcher, W.W., \& Santos, J.E.P. (2016). Carryover effect of postpartum inflammatory diseases on developmental biology and fertility in lactating dairy cows. Journal of Dairy Science, 99, 2201-2220. DOI: 10.3168/jds.2015-10337.

19. Roche, J.F. (2006). The effect of nutritional management of the dairy cow on reproductive efficiency. Animal Reproduction. Science, 96, 282-296. DOI: 10.1016/j.anireprosci.2006.08.007.

20. Roche, J.R., Friggens, N.C., Kay, J.K., Fisher, M.W., Stafford, K.J., \& Berry, D.P. (2009). Invited review: body condition score and its association with dairy cow productivity, health, and welfare. Journal of. Dairy Science, 92, 5769-5801. DOI: 10.3168/jds2009-2431.

21. Roche, J.R., Burke, C.R., Crookenden, M.A., Heiser, A., Loor, I.L., Meier, S., Mitchell, M.D., Phyn, C.V.C., $\&$ Turner, S.-A. (2018). Fertility and the transition dairy cow. Reproduction, Fertility and Development, 30, 85-100. DOI: 10.1071/RD17412.

22. Shabankareh, H.K., Kor, N.M., \& Hajarian, H. (2013). The influence of the corpus luteum on metabolites composition of follicular fluid from different sized follicles and their relationship to serum concentrations in dairy cows. Animal Reproduction Science, 140, 109-114.

23. Snijders, S.E.M., Dillon, P.O’Callaghan, D., \& Boland, M.P. (2000). Effect of genetic merit, milk yield, body condition and lactation number on in vitro oocyte development in dairy cows. Theriogenology, 53, 981-989. DOI: 10.1016/S0093-691X (00)00244-2.

24. Son, J., Jung, Y., Cho, S., Baek, K., Yoon, H., Lim, H., Kwon, E., Kim, S., \& Choe, C. (2012). Relationship between transferable embryos and major metabolite concentrations in Holstein donor cows. Journal of Embryo Transfer, 27, 4, 229-235.

25. Walsh, S.W., Williams, E.J., \& Evans, A.C.O. (2011). A review of the causes of poor fertility in high milk producing dairy cows. Animal Reproduction Science, 123, 127-138. DOI: 10.1016/j. anireprosci.2010.12.001. 